\title{
Dissemination of extensively drug-resistant and KPC-2 producing Klebsiella pneumoniae isolated from bloodstream infections
}

\author{
Feng Zhao, Jun Zhang, Ying Fu, Zhi Ruan, Xinyou Xie \\ Department of Clinical Laboratory, Sir Run Run Shaw Hospital, School of Medicine, Zhejiang University, Hangzhou, \\ Zhejiang, People's Republic of China
}

\begin{abstract}
Introduction: Bloodstream infections (BSIs) are serious diseases associated with high mortality, especially when caused by extensively drugresistant (XDR) Klebsiella pneumoniae. The prevalence and pandemic strains of extended-spectrum beta-lactamase (ESBL)-producing K. pneumoniae isolated from blood cultures of patients with BSIs were determined at Sir Run Run Shaw Hospital, China.

Methodology: A total of 24 XDR K. pneumoniae were isolated from blood cultures, and the clinical data of the patients were analyzed retrospectively. Bacterial species identification and antimicrobial susceptibility testing were performed using VITEK2 and E-test methods, respectively. Common ESBL-resistant genes were amplified and sequenced after the validation of a modified Hodge test. Strain homology was also analyzed by pulsed-field gel electrophoresis (PFGE).

Results: All of the isolates were resistant to 10 antimicrobial agents. Several strains showed partial sensitivity to aminoglycosides, but all showed sensitivity to polymyxin and tigecycline. All strains were Klebsiella pneumoniae carbapenemase (KPC-2) producing, and carried two or three ESBL-resistant genes, which belonged to 13 PFGE clones (A-M). The overall mortality rate in patients was as high as $29.2 \%$.

Conclusions: KPC-2-producing K. pneumoniae BSIs are associated with high mortality rates. Our observations suggest that KPC-2 and ESBL-producing $K$. pneumoniae might be responsible for the clonal dissemination of extensively drug-resistant isolates in our hospital.
\end{abstract}

Key words: bloodstream infection; extensively drug-resistant; Klebsiella pneumoniae; ESBLs; clonal dissemination.

J Infect Dev Ctries 2015; 9(9):1016-1021. doi:10.3855/jidc.6679

(Received 02 February 2015 - Accepted 19 June 2015)

Copyright (C) 2015 Zhao et al. This is an open-access article distributed under the Creative Commons Attribution License, which permits unrestricted use, distribution, and reproduction in any medium, provided the original work is properly cited.

\section{Introduction}

Bloodstream infections (BSIs) caused by Klebsiella pneumoniae carbapenemases (KPC)producing $K$. pneumoniae are associated with high mortality rates. [1]. The isolation rate of resistant bacteria in BSIs has increased significantly with the rampant use of beta-lactams and aminoglycoside antibiotics, as well as the development of more invasive procedures and treatments [2]. The Chinese Ministry of Health National Antimicrobial Resistance Investigation Net annual reports of 2010 and 2011 estimated that the isolation rate of $K$. pneumoniae, which has become one of the most common pathogenic bacteria in BSIs, was $7.7 \%$ and $8.3 \%$, respectively $[3,4]$. In this study, a total of $252 \mathrm{~K}$. pneumoniae isolates were recovered from the blood of patients at Sir Run Run Shaw Hospital, a tertiary hospital, over the past two years; of the isolates, 24 were extensively drug-resistant strains. We investigated the prevalent characteristics of extensively drug-resistant (XDR) $K$. pneumoniae isolates in BSIs, which were resistant to almost all 15 antimicrobial agents tested. We also tested the $\beta$ lactamase genotypes, examined the clonal relatedness of the strains, and analyzed the clinical data of patients to provide evidence for nosocomial infection.

\section{Methodology}

Bacterial strains

From August 2010 to December 2012, clinical non-duplicate, consecutive $K$. pneumoniae isolates were recovered from BSIs of inpatients at Sir Run Run Shaw Hospital, School of Medicine, Zhejiang University. Bacterial species identification was performed using the VITEK2 system (BioMérieux, Marcy 1'Etoile, France), and the identified XDR strains were included in this analysis [5]. The clinical data of these patients were also collected and analyzed.

\section{Instruments and reagents}

Both the VITEK2 system and the E-test method (AB bioMérieux, Solna, Sweden) were used to investigate the antimicrobial susceptibility profile. 
CHEF pulsed field gel electrophoresis (PFGE), polymerase chain reaction (PCR), and gel image analysis systems were applied (all from Bio-Rad, Hercules, USA). A PCR amplification kit and the endonucleases $A p a \mathrm{I}$ and $X b a \mathrm{I}$ (TAKARA Bio Inc., Kusatsu, Japan,) were used to amplify common $\beta$ lactamase genes for the modified Hodge test (MHT)positive strains.

\section{Susceptibility test}

The minimum inhibitory concentrations (MICs) of ceftazidime (CAZ), cefepime (FEP), cefotetan (CTT), aztreonam (ATM), ampicillin/sulbactam (SAM), piperacillin/tazobactam (TZP), ertapenem (ETP), imipenem (IPM), gentamycin (GEN), tobramycin (TOB), amikacin (AMK), and levofloxacin hydrochloride (LVX) were determined with an automated microbiology analyzer (VITEK2). The MICs of polymyxin (CST), tigecycline (TGC), and meropenem (MEM) were determined using the E-test. Quality control strains for the susceptibility test included E. coli ATCC 25922, following the Clinical and Laboratory Standards Institute (CLSI)'s 2013 guidelines. A modified Hodge test (MHT) was performed to detect carbapenemases in accordance with the guidelines recommended by CLSI 2013.

\section{PCR amplification of $\beta$-lactamase and DNA sequencing}

PCR amplification of common $\beta$-lactamase genes was performed for MHT-positive strains. The amplified genes included $b l a_{\mathrm{KPC}}, b l a_{\mathrm{IPM}}, b l a_{\mathrm{VIM}}, b l a_{\mathrm{SPM}-}$ 1, $b l a_{\mathrm{GIM}}, b l a_{\mathrm{SIM}-1}, b l a_{\mathrm{NDM}-1}, b l a_{\mathrm{OXA}-48}, b l a_{\mathrm{TEM}}, b l a_{\mathrm{SHV}}$, $b l a_{\text {СТХ-М }}\left(b l a_{\text {СТХ-М-1 }}, b l a_{\text {СТХ-М-2 }}, b l a_{\text {СТХ-М-8}}, b l a_{\text {СТХ-М-9 }}\right)$, bla $a_{\mathrm{DHA}}, b l a_{\mathrm{MIR}}, b l a_{\mathrm{ACC}}$, and bla $a_{\mathrm{CIT}}$. Bacterial DNA template was extracted by the boiling method according to the previously reported protocol [6]. PCR reactions were designed as follows: pre-denaturation at $94^{\circ} \mathrm{C}$ for 5 minutes, followed by 35 cycles of denaturation at $95^{\circ} \mathrm{C}$ for 1 minute, annealing at $55^{\circ} \mathrm{C}$ for 30 seconds, and extension at $72^{\circ} \mathrm{C}$ for 40 seconds. PCR products were confirmed by $1 \%$ agarose gel electrophoresis, and images were acquired under a UV lamp. Positive PCR products were sent to Bo Shang Biotechnology Co. for DNA sequencing. The sequence analyses were performed using the BLAST program available on the National Center for Biotechnology Information server (http://blast.ncbi.nlm.nih.gov/).
Pulsed-field gel electrophoresis (PFGE)

The clonal relatedness of the isolates was determined with PFGE, as described previously [6]. A suspension of $0.5 \mathrm{McF}$ arland bacteria was embedded in agarose and digested with $\mathrm{XbaI}$ for 4 hours at $37^{\circ} \mathrm{C}$ in advance. PFGE conditions were as follows: $6 \mathrm{~V} / \mathrm{cm}^{2}$ for 22 hours, with an initial pulse time of 5 seconds and a final pulse time of 25 seconds. PFGE patterns were read according to criteria defined by Tenover et al. [7] as follows: indistinguishable, variation in 1-3 bands; closely related, variation in 4-6 bands; and unrelated, variation in 7 or more bands. The phylogenetic tree was constructed by BioNumerics software version 7.0.

\section{Results}

Demographic and clinical characteristics of the patients

In total, 24 XDR $K$. pneumoniae isolates associated with BSIs were isolated from the following departments: intensive care unit (ICU) $(\mathrm{n}=11)$, hematology $(\mathrm{n}=4)$, gastroenterology $(\mathrm{n}=3)$, infectious diseases $(n=1)$, general surgery $(n=3)$, and urology $(n=2)$. Nineteen patients were male, and five were female. Patients' ages ranged from 30 to 84 years (mean age, $61.3 \pm 14.2$ years), and 16 patients were 60 years of age or older. A total of 4 patients were diagnosed with malignant tumors; 4 with leukemia or other blood diseases; 8 with cholecystitis and other diseases of the digestive system; 2 were cases of trauma; and 6 had hypertension, diabetes, or other chronic diseases. A total of 19 patients received catheter intervention, and 24 patients received betalactamase antibiotics before the isolation of $K$. pneumoniae. Fourteen days after being infected, 17 patients were alive and 7 had died; the mortality rate was $29.2 \%$. The clinical and demographic information of the patients are listed in Table 1.

\section{Antimicrobial susceptibility results}

Antimicrobial susceptibility tests for 15 antibiotics showed that all of the isolates were resistant to penicillin, cephalosporins, penicillin or penicillin enzyme inhibitors, aztreonam, and fluoroquinolones. Three strains were susceptible to aminoglycoside antibiotics, tobramycin, and amikacin. All 24 isolates were sensitive to polymyxin and tigecycline, and the results are listed in Table 2. The MICs were interpreted according to the 2013 CLSI guidelines. 
PCR amplification of $\beta$-lactamase and DNA sequencing

MHTs were positive for all strains. PCR demonstrated a high prevalence of $\beta$-lactamase genes. The sequencing results were compared with the GenBank database, and the corresponding genotypes were $b l a_{\mathrm{KPC}-2}, b l a_{\mathrm{TEM}-1}, b l a_{\mathrm{SHV}-11}, b l a_{\mathrm{SHV}-12}, b l a_{\mathrm{CTX}-\mathrm{M}-3}$, $b l a_{\text {CTX-M-16, }}, b l a_{\text {CTX-М-24, }}$ and $b l a_{\text {DHA-1. }}$ The results of drug-resistance gene amplification are shown in Figure 1. Both of the $b l a_{\mathrm{KPC}-2}$ and bla $a_{\mathrm{TEM}-1}$ genes were identified in all the 24 strains. Twenty-one carried $b l a_{\mathrm{SHV}}, 17$ of which carried $b l a_{\mathrm{SHV}-11}$, and 4 of which carried $b l a_{\mathrm{SHV}-12}$. Twenty-two strains carried $b l a_{\text {СтХ-м, }}$ 15 of which carried $b l a_{\text {CTX-М-24, }} 4$ of which carried $b l a_{\text {СтХ-м-3}}$, and 3 of which carried $b l a_{\text {СтХ-М-16. All of }}$ the strains co-carried two or three ESBL-resistant genes. Nine strains co-carried $b l a_{\mathrm{TEM}-1}, b l a_{\mathrm{SHV}-11}$ and $b l a_{\mathrm{CTX}-\mathrm{M}-24}$. Four strains co-carried $b l a_{\mathrm{TEM}-1}, b l a_{\mathrm{SHV}-12}$, and $b l a_{\mathrm{CTX}-\mathrm{M}-24}$. Three strains co-carried $b l a_{\mathrm{TEM}-1}$ and $b l a_{\mathrm{SHV}-11}$. Two strains co-carried $b l a_{\mathrm{TEM}-1}, b l a_{\text {СTX-M-3, }}$,

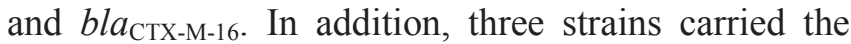
AmpC gene $\left(b l a_{\mathrm{DHA}-1}\right)$. The $b l a_{\mathrm{IPM}}, b l a_{\mathrm{VIM}}, b l a_{\mathrm{SPM}-1}$, $b_{\mathrm{GIM}}, b l a_{\mathrm{SIM}-1}, b l a_{\mathrm{NDM}-1}, b l a_{\mathrm{OXA}-48}, b l a_{\mathrm{ACC}}$, and $b l a_{\mathrm{CIT}}$ gene tests were negative in all strains.
Figure 1. PFGE analysis and $\beta$-lactamase genes of the $24 \mathrm{~K}$. pneumoniae strains of bloodstream infections

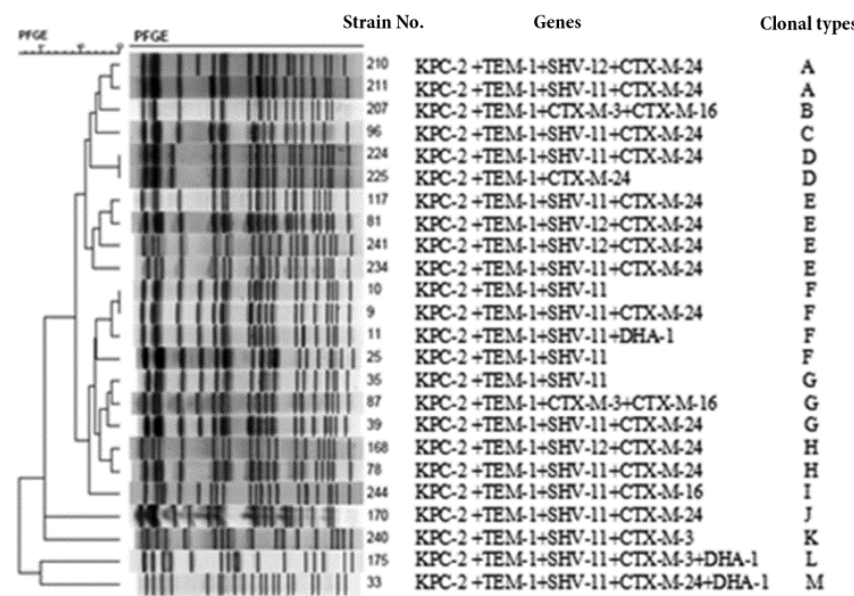

Table 1. Demographic and clinical characteristics of the 24 patients with extensively drug-resistant K. pneumoniae strains of bloodstream infections

\begin{tabular}{|c|c|c|c|c|c|c|c|c|}
\hline $\begin{array}{l}\text { Strain } \\
\text { No. }\end{array}$ & Date & Department & Sex & Age & Clinical diagnosis & $\begin{array}{c}\text { Alive or dead } \\
\text { on day } 14 \\
\end{array}$ & $\begin{array}{l}\text { History of } \\
\text { stay in ICU }\end{array}$ & $\begin{array}{l}\text { History of catheter } \\
\text { treatment }\end{array}$ \\
\hline 9 & $2010-08-20$ & Urology & Male & 79 & $\begin{array}{l}\text { Postoperative colorectal cancer, } \\
\text { hypertension }\end{array}$ & Alive & No & No \\
\hline 10 & $2010-08-30$ & Urology & Female & 53 & Polycystic kidney, hypertension, diabetes & Alive & Yes & $\begin{array}{l}\text { Left double-J } \\
\text { catheter }\end{array}$ \\
\hline 11 & $2010-08-25$ & Hematology & Male & 46 & Acute leukemia & Alive & No & PICC \\
\hline 25 & $2010-11-14$ & Hematology & Male & 47 & Acute leukemia & Dead & No & Subclavian catheter \\
\hline 33 & $2010-12-07$ & $\mathrm{ICU}$ & Male & 30 & Multiple trauma of brain injury & Alive & Yes & Subclavian catheter \\
\hline 35 & $2010-12-12$ & $\mathrm{ICU}$ & Male & 73 & Coronary bypass, hypertension, diabetes & Alive & Yes & PICC \\
\hline 39 & $2010-12-30$ & Hematology & Male & 54 & Acute leukemia, hypertension & Dead & Yes & PICC \\
\hline 78 & 2011-06-07 & $\mathrm{ICU}$ & Male & 75 & Left adrenal tumor & Alive & Yes & Intravenous catheter \\
\hline 81 & 2011-06-18 & ICU & Male & 67 & Esophageal cancer & Dead & Yes & Abdominal drain \\
\hline 87 & $2012-07-22$ & $\mathrm{ICU}$ & Female & 33 & Hemolytic anemia & Dead & Yes & Intravenous catheter \\
\hline 96 & 2011-11-12 & ICU & Male & 74 & Acute pancreatitis & Alive & Yes & Intravenous catheter \\
\hline 117 & $2012-02-02$ & $\mathrm{ICU}$ & Male & 65 & COPD, diabetes, hypertension & Alive & Yes & Intravenous catheter \\
\hline 168 & 2012-02-06 & Gastroenterology & Female & 80 & Acute cholecystitis & Alive & No & No \\
\hline 170 & 2012-02-11 & $\mathrm{ICU}$ & Male & 74 & Arteriosclerotic obliteration & Alive & Yes & $\begin{array}{l}\text { Jugular vein } \\
\text { catheter }\end{array}$ \\
\hline 175 & 2012-04-04 & $\mathrm{ICU}$ & Male & 84 & Arterial embolism & Dead & Yes & Intravenous catheter \\
\hline 207 & $2012-11-21$ & Infectious disease & Male & 52 & Calculus of bile duct & Alive & No & T-tube drain \\
\hline 210 & $2012-05-04$ & $\mathrm{ICU}$ & Male & 60 & Septic shock, hypertension, diabetes & Dead & Yes & $\begin{array}{l}\text { Femoral vein blood } \\
\text { dialysis tube }\end{array}$ \\
\hline 211 & $2012-05-08$ & General surgery & Female & 40 & Liver tumor & Alive & No & Intravenous catheter \\
\hline 224 & $2012-05-26$ & General surgery & Male & 68 & Carcinoma of ampulla & Alive & No & No \\
\hline 225 & $2012-06-03$ & Gastroenterology & Female & 62 & Obstructive jaundice & Alive & No & No \\
\hline 234 & 2012-06-09 & General surgery & Male & 61 & Cholecystitis & Alive & No & Intravenous catheter \\
\hline 240 & $2012-06-12$ & $\mathrm{ICU}$ & Male & 64 & Lung contusion & Alive & Yes & Intravenous catheter \\
\hline 241 & $2012-07-22$ & Gastroenterology & Male & 66 & Acute pancreatitis, hypertension & Alive & No & No \\
\hline 244 & $2012-11-21$ & Hematology & Male & 64 & Malignant lymphoma & Dead & Yes & Intravenous catheter \\
\hline
\end{tabular}

ICU: intensive care unit; PICC: peripherauy inserted central catheter; COPD: chronic obstructive pulmonary disease 
Pulsed-field gel electrophoresis (PFGE)

The 24 isolates belonged to 13 PFGE clones (AM): A clone $(n=2), B$ clone $(n=1), C$ clone $(n=1)$, D clone $(n=2), E$ clone $(n=4), F$ clone $(n=4), G$ clone $(\mathrm{n}=3), \mathrm{H}$ clone $(\mathrm{n}=2)$, I clone $(\mathrm{n}=1), \mathrm{J}$ clone $(\mathrm{n}=1), \mathrm{K}$ clone $(\mathrm{n}=1)$, and $\mathrm{L}$ clone $(\mathrm{n}=1)$. The distribution according to department was as follows: ICU, 9 clones for 11 strains; gastroenterology, 3 clones for 3 strains; hematology, 3 clones for 4 strains; general surgery, 3 clones for 3 strains; urology, 1 clone for 2 strains; and infectious disease, 1 clone for 1 strain. The $\beta$-lactamase genotypes of the same clone were almost the same. PFGE clones and department distribution are shown in Figure 1.

\section{Discussion}

Previous studies have indicated that long-term use of catheters is the main cause of BSIs, and that the frequent use of antibiotics such as carbapenems is one of the main risk factors associated with antimicrobial resistance acquisition in $K$. pneumoniae [8]. The retrospective analysis in our study showed that among
24 cases, 9 cases had malignant disease; 6 cases had digestive disease; 7 cases had hypertension, diabetes and various types of chronic disease; and only 2 cases were of traumatic injury. Before the isolation of XDR $K$. pneumoniae, most of the patients had been exposed to invasive procedures, and all of the patients had received $\beta$-lactamase antibiotics. The elderly accounted for the majority of our patients, most of whom had chronic diseases. It is reasonable to postulate that due to their weakened immune systems, exposure to antimicrobial therapy, and invasive devices, these patients are likely to have significantly different risk factors compared to normal patients $[8,9]$. With these confounding variables, patients infected with multi-drug resistant bacteria also have an increased mortality risk [10]. The 14-day mortality for patients with drug-resistant $K$. pneumoniae BSIs has been reported to be up to $41.7 \%$ [11]. The overall mortality in our patients was high $(29.2 \%)$, similar to that observed in other studies [10,11].

Carbapenems have been widely utilized as the treatment of choice for serious infections caused by

Table 2. Antimicrobial susceptibility profiles of the 24 extensively drug-resistant $K$. pneumoniae strains of bloodstream infections

\begin{tabular}{|c|c|c|c|c|c|c|c|c|c|c|c|c|c|c|c|}
\hline $\begin{array}{c}\text { Strain } \\
\text { No. }\end{array}$ & \multicolumn{15}{|c|}{$\operatorname{MIC}(\mu \mathrm{g} / \mathrm{mL})^{*}$} \\
\hline 9 & $\geq 64$ & $\geq 64$ & $\geq 64$ & $\geq 64$ & $\geq 32$ & $\geq 128$ & $\geq 8$ & $\geq 16$ & $\geq 16$ & $\geq 16$ & $\geq 16$ & $\geq 64$ & $\geq 8$ & 2 & 0.38 \\
\hline 11 & $\geq 64$ & $\geq 64$ & $\geq 64$ & $\geq 64$ & $\geq 32$ & $\geq 128$ & $\geq 8$ & $\geq 16$ & $\geq 16$ & $\geq 16$ & $\geq 16$ & $\geq 64$ & $\geq 8$ & 2 & 0.38 \\
\hline 25 & $\geq 64$ & $\geq 64$ & $\geq 64$ & $\geq 64$ & $\geq 32$ & $\geq 128$ & $\geq 8$ & $\geq 16$ & $\geq 16$ & 1 & $\leq 4$ & $\leq 2$ & $\geq 8$ & 0.5 & 0.25 \\
\hline 33 & $\geq 64$ & $\geq 64$ & $\geq 64$ & $\geq 64$ & $\geq 32$ & $\geq 128$ & $\geq 8$ & $\geq 16$ & $\geq 16$ & $\geq 16$ & $\leq 4$ & $\leq 2$ & $\geq 8$ & 1 & 0.19 \\
\hline 39 & $\geq 64$ & $\geq 64$ & $\geq 64$ & $\geq 64$ & $\geq 32$ & $\geq 128$ & $\geq 8$ & $\geq 16$ & $\geq 16$ & $\geq 16$ & $\geq 16$ & $\geq 64$ & $\geq 8$ & 1 & 0.75 \\
\hline 78 & $\geq 64$ & $\geq 64$ & $\geq 64$ & $\geq 64$ & $\geq 32$ & $\geq 128$ & $\geq 8$ & $\geq 16$ & $\geq 16$ & $\geq 16$ & $\geq 16$ & $\geq 64$ & $\geq 8$ & 2 & 0.38 \\
\hline 81 & $\geq 64$ & $\geq 64$ & $\geq 64$ & $\geq 64$ & $\geq 32$ & $\geq 128$ & $\geq 8$ & $\geq 16$ & $\geq 16$ & $\geq 16$ & $\geq 16$ & $\geq 64$ & $\geq 8$ & 0.75 & 0.25 \\
\hline 87 & 32 & $\geq 64$ & $\geq 64$ & $\geq 64$ & $\geq 32$ & $\geq 128$ & $\geq 8$ & $\geq 16$ & $\geq 16$ & $\geq 16$ & $\geq 16$ & $\geq 64$ & $\geq 8$ & 1.5 & 0.25 \\
\hline 96 & $\geq 64$ & $\geq 64$ & $\geq 64$ & $\geq 64$ & $\geq 32$ & $\geq 128$ & $\geq 8$ & $\geq 16$ & $\geq 16$ & $\geq 16$ & $\geq 16$ & $\geq 64$ & $\geq 8$ & 0.19 & 0.19 \\
\hline 117 & $\geq 64$ & $\geq 64$ & $\geq 64$ & $\geq 64$ & $\geq 32$ & $\geq 128$ & $\geq 8$ & $\geq 16$ & $\geq 16$ & $\geq 16$ & $\geq 16$ & $\geq 64$ & $\geq 8$ & 1 & 0.38 \\
\hline 210 & $\geq 64$ & $\geq 64$ & $\geq 64$ & $\geq 64$ & $\geq 32$ & $\geq 128$ & $\geq 8$ & $\geq 16$ & $\geq 16$ & $\geq 16$ & $\geq 16$ & $\geq 64$ & $\geq 8$ & 1.5 & 0.38 \\
\hline 211 & 32 & $\geq 64$ & $\geq 64$ & $\geq 64$ & $\geq 32$ & $\geq 128$ & $\geq 8$ & $\geq 16$ & $\geq 16$ & $\geq 16$ & $\geq 16$ & $\geq 64$ & $\geq 8$ & 0.5 & 0.38 \\
\hline 224 & $\geq 64$ & $\geq 64$ & $\geq 64$ & $\geq 64$ & $\geq 32$ & $\geq 128$ & $\geq 8$ & $\geq 16$ & $\geq 16$ & $\geq 16$ & $\geq 16$ & $\geq 64$ & $\geq 8$ & 0.75 & 0.125 \\
\hline 225 & $\geq 64$ & $\geq 64$ & $\geq 64$ & $\geq 64$ & $\geq 32$ & $\geq 128$ & $\geq 8$ & $\geq 16$ & $\geq 16$ & $\geq 16$ & $\geq 16$ & $\geq 64$ & $\geq 8$ & 0.75 & 0.125 \\
\hline 234 & $\geq 64$ & $\geq 64$ & $\geq 64$ & $\geq 64$ & $\geq 32$ & $\geq 128$ & $\geq 8$ & $\geq 16$ & $\geq 16$ & $\geq 16$ & $\geq 16$ & $\geq 64$ & $\geq 8$ & 0.38 & 0.38 \\
\hline 240 & 32 & $\geq 64$ & 32 & $\geq 64$ & $\geq 32$ & $\geq 128$ & $\geq 8$ & 8 & 4 & $\leq 1$ & $\leq 4$ & $\leq 2$ & $\geq 8$ & 1 & 0.25 \\
\hline 241 & $\geq 64$ & $\geq 64$ & $\geq 64$ & $\geq 64$ & $\geq 32$ & $\geq 128$ & $\geq 8$ & $\geq 16$ & $\geq 16$ & $\geq 16$ & $\geq 16$ & $\geq 64$ & $\geq 8$ & 0.75 & 0.25 \\
\hline 244 & $\geq 64$ & $\geq 64$ & $\geq 64$ & $\geq 64$ & $\geq 32$ & $\geq 128$ & $\geq 8$ & $\geq 16$ & $\geq 16$ & $\geq 16$ & $\leq 4$ & $\leq 2$ & $\geq 8$ & 1.5 & 0.19 \\
\hline
\end{tabular}

CAZ: ceftazidime; FEP: cefepime; CTT: cefotetan; ATM: aztreonam; SAM: ampicillin/sulbactam; TZP: piperacillin/tazobactam; ETP: ertapenem; IPM: imipenem; MEM: meropenem; GEN: gentamycin; TOB: tobramycin; AMK: amikacin; LVX: levofloxacin hydrochloride; TGC: tigecycline; CST: polymyxin; "MICs were interpreted according to the CLSI 2013 guidelines 
ESBL producers, exerting selection pressure for carbapenem resistance acquisition [5]. Carbapenemresistant $K$. pneumoniae, especially KPC-2-producing isolates, have been therefore disseminated globally and pose remarkable clinical and therapeutic challenges [12]. The increasing prevalence of severe infections with high mortality rates underlines the need for effective treatment. In our study, antimicrobial susceptibility tests showed that all of the 24 KPC-2 positive isolates were extensively drugresistant and completely resistant to penicillin, cephalosporins, penicillin/penicillin enzyme inhibitors, aztreonam, and fluoroquinolones. These strains were highly resistant to carbapenems, but only susceptible to polymyxin and tigecycline, which have been ultimately considered as the last-resort treatment for such infections. Previous research demonstrated that antimicrobial-resistant $K$. pneumoniae isolates could carry multiple resistance genes simultaneously $[13,14]$. In our study, a high prevalence of $\beta$-lactamase genes was observed. All of the strains carried bla $a_{\mathrm{TEM}-1}$, 21 carried $b l a_{\mathrm{SHV}-11}$ or $b l a_{\mathrm{SHV}-12}$, and 21 carried $b l a_{\mathrm{CTX}}$ м. Among $b l a_{\text {СтХ-м }}$ carriers, 15 strains carried $b l a_{\text {СтХ-м- }}$ 24, indicating that $b l a_{\text {CTХ-M-24 was the major epidemic }}$ type of $b l a_{\mathrm{CTX}-\mathrm{M}}$, and 3 strains carried $b l a_{\mathrm{DHA}-1}$. All of the strains carried multiple resistance determinants in various combinations, especially the combination of bla $a_{\mathrm{TEM}-1}, \quad b l a_{\mathrm{SHV}-11}$, and bla $a_{\mathrm{CTX}-\mathrm{M}-24}$. According to previous studies both in China and the United States of America (USA), the most commonly identified $b l a_{\text {СтХ- }}$ м type was bla СтХ-м-15 $_{\text {in }}$ K. pneumoniae $[15,16]$. However, this study reports, for the first time, that in our hospital, $b l a_{\mathrm{CTX}-\mathrm{M}-24}$ is the major type of $b l a_{\mathrm{CTX}-\mathrm{M}}$ and should be monitored with care.

PFGE analysis showed that 24 XDR $K$. pneumoniae BSIs in our hospital had 13 clonal clusters (A-M). Eleven isolates in the ICU were from 9 clusters; only 2 strains were type E, 2 were type G, and the remaining 7 strains had different spectral types. Moreover, J, K, L, and M types appeared only in the ICU, and the other 5 types were detected in other departments. This distribution could be primarily due to the high frequency of transfer of critically ill patients in the ICU ward. Patients are transferred to the ICU when they are critically ill, and they are transferred back to their designated ward when they are in stable condition. Therefore, the ICU has become an important route of transmission by which bacterial strains are embedded and then disseminated to other patients. Strains are then carried to other departments with the patients as they recover and leave, or as they are transferred between units for specialized procedures or treatment. In our study, the clonal spread existed not only between the ICU and other departments, but also among other departments. For example, strain No. 224 was isolated from a patient with ampullary carcinoma in the department of general surgery, and strain No. 225 was collected from a patient with obstructive jaundice in the gastroenterology department. Patient No. 224 had an endoscopic retrograde cholangiopancreatography (ERCP), and patient No. 225 also received the same procedure. Interestingly, D clonal type XDR $K$. pneumoniae could also have been isolated from both departments. Thus, it is reasonable to speculate that the use of medical devices is another risk factor that causes XDR $K$. pneumoniae transmission among different departments. Therefore, we concluded that simultaneous sporadic and clonal dissemination were responsible for the wide distribution of XDR $K$. pneumoniae isolated in multiple departments of our hospital.

\section{Conclusions}

It is evident that most of the BSI patients with XDR $K$. pneumoniae had malignant and chronic diseases with high mortality. The XDR K. pneumoniae isolates harbouring $b l a_{\mathrm{KPC}-2}$ also carried several ESBLresistant genes, and the strain spread between the ICU and other departments in both was both sporadic and clonal. Screening and surveillance of XDR $K$. pneumoniae is urgently needed in our hospital to control and prevent the further spread of these resistance genes and resistant organisms.

\section{Acknowledgements}

This study was supported partly by the grants from National Natural Science Foundation of China (81271914), Zhejiang Provincial Natural Science Foundation (LY12H16025), Science Foundation of Health Bureau of Zhejiang Province (Nos. 2008B114 and 2011KYA081), Science Foundation of Education Bureau of Zhejiang Province (Y201121182), and Funds for Key Program of the Science Technology Department Zhejiang Province (2012C13019-2). The funders had no role in study design, data collection and analysis, decision to publish, or preparation of the manuscript.

\section{References}

1. Yeh CF, Chen KF, Ye JJ, Huang CT (2014) Derivation of a clinical prediction rule for bloodstream infection mortality of patients visiting the emergency department based on predisposition, infection, response, and organ dysfunction concept. J Microbiol Immunol Infect 47: 469-477. 
2. Collins VL, Marchaim D, Pogue JM, Moshos J, Bheemreddy S, Sunkara B, Shallal A, Chugh N, Eiseler S, Bhargava P, Blunden C, Lephart PR, Memon BI, Hayakawa K, AbreuLanfranco O, Chopra T, Munoz-Price LS, Carmeli Y, Kaye KS (2012) Efficacy of ertapenem for treatment of bloodstream infections caused by extended-spectrum-betalactamase-producing Enterobacteriaceae. Antimicrob Agents Chemother 56: 2173-2177.

3. Ma X, Lu Y, Xue F (2011) Mohnarin report 2010: surveillance for resistance of bacteria causing bloodstream infection. Chinese J Nosocomiol 24: 5147-5151.

4. Ma X, Lu Y, Zheng B (2012) Ministry of Health National Antimicrobial Resistance Investigation Net annual report of 2011: bacterial distribution and resistance in bloodstream infection. Chin J Clin Pharmacol 28: 927-932.

5. Magiorakos AP, Srinivasan A, Carey RB, Carmeli Y, Falagas ME, Giske CG, Harbarth S, Hindler JF, Kahlmeter G, OlssonLiljequist B, Paterson DL, Rice LB, Stelling J, Struelens MJ, Vatopoulos A, Weber JT, Monnet DL (2012) Multidrugresistant, extensively drug-resistant and pandrug-resistant bacteria: an international expert proposal for interim standard definitions for acquired resistance. Clin Microbiol Infect 18: 268-281.

6. Gouby A, Neuwirth C, Bourg G, Bouziges N, Carles-Nurit MJ, Despaux E, Ramuz M (1994) Epidemiological study by pulsed-field gel electrophoresis of an outbreak of extendedspectrum beta-lactamase-producing Klebsiella pneumoniae in a geriatric hospital. J Clin Microbiol 32: 301-305.

7. Tenover FC, Arbeit RD, Goering RV, Mickelsen PA, Murray BE, Persing DH, Swaminathan B (1995) Interpreting chromosomal DNA restriction patterns produced by pulsedfield gel electrophoresis: criteria for bacterial strain typing. J Clin Microbiol 33: 2233-2239.

8. Bouza E, Eworo A, Fernandez Cruz A, Reigadas E, Rodriguez-Creixems M, Muñoz P (2013) Catheter-related bloodstream infections caused by Gram-negative bacteria. J Hosp Infect 85: 316-320.

9. Ben-David D, Kordevani R, Keller N, Tal I, Marzel A, GalMor O, Maor Y, Rahav G (2012) Outcome of carbapenem resistant Klebsiella pneumoniae bloodstream infections. Clin Microbiol Infect 18: 54-60.

10. Viale P, Giannella M, Lewis R, Trecarichi EM, Petrosillo N, Tumbarello M (2013) Predictors of mortality in multidrug- resistant Klebsiella pneumoniae bloodstream infections. Expert Rev Anti Infect Ther 11: 1053-1063.

11. Neuner EA, Yeh JY, Hall GS, Sekeres J, Endimiani A, Bonomo RA, Shrestha NK, Fraser TG, van Duin D (2011) Treatment and outcomes in carbapenem-resistant Klebsiella pneumoniae bloodstream infections. Diagn Microbiol Infect Dis 69: $357-362$.

12. Shen P, Wei Z, Jiang Y, Du X, Ji S, Yu Y, Li L (2009) Novel genetic environment of the carbapenem-hydrolyzing betalactamase KPC-2 among Enterobacteriaceae in China. Antimicrob Agents Chemother 53: 4333-4338.

13. Poulou A, Voulgari E, Vrioni G, Koumaki V, Xidopoulos G, Chatzipantazi V, Markou F, Tsakris A (2013) Outbreak caused by an ertapenem-resistant, CTX-M-15-producing Klebsiella pneumoniae sequence type 101 clone carrying an OmpK36 porin variant. J Clin Microbiol 51: 3176-3182.

14. Tawfik AF, Alswailem AM, Shibl AM, Al-Agamy $\mathrm{MH}$ (2011) Prevalence and genetic characteristics of TEM, SHV, and CTX-M in clinical Klebsiella pneumoniae isolates from Saudi Arabia. Microb Drug Resist 17: 383-388.

15. Castanheira M, Farrell SE, Deshpande LM, Mendes RE, Jones RN (2013) Prevalence of beta-lactamase-encoding genes among Enterobacteriaceae bacteremia isolates collected in 26 U.S. hospitals: report from the SENTRY Antimicrobial Surveillance Program (2010). Antimicrob Agents Chemother 57: 3012-3020.

16. Liu Y, Li XY, Wan LG, Jiang WY, Yang JH, Li FQ (2013) Acquisition of carbapenem resistance in multiresistant Klebsiella pneumoniae isolates of sequence type 11 at a university hospital in China. Diagn Microbiol Infect Dis 76: 241-243.

\section{Corresponding author}

Xinyou Xie

No. 3 Qingchun East Road

Department of Clinical Laboratory

Sir Run Run Shaw Hospital, School of Medicine

Zhejiang University, Hangzhou

Zhejiang, 310016, People's Republic of China

Phone: + 86-571-86002064

Fax: + 86-571-86002064

E-mail: scottxie@mail.hz.zj.cn

Conflict of interests: No conflict of interests is declared. 